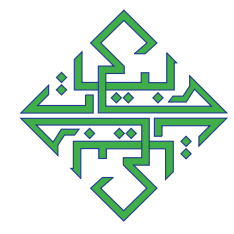

\title{
PEMBELAJARAN BAHASA ARAB DI ERA POSMETODE
}

\author{
Muhbib Abdul Wahab \\ Universitas Islam Negeri Syarif Hidayatullah Jakarta \\ e-mail : muhbib@uinjkt.ac.id
}

Naskah diterima: 6 Februari 2015, direvisi: 13 Maret 2014, disetujui: 5 Mei 2015.

\begin{abstract}
This article is aimed to answer two essential problems; (1) development map of Arabic learning method from 1990s until today which has been formulated unclearly, and (2) developing Arabic learning in posmethod era by optimilizing teacher's strategic role in the process of Arabic learning. This article used bibliographic sources from some books and articles in scientific journal about linguistic and Arabic learning. The interpretation data of academician thought and Arabic linguistic experts was done by using historical-critical approach and content analysis for substancial interpretation. B. Kumaravadivelu concept in Beyond Methods: Macrostrategies for Language Teaching (2003) which requires teacher to play three essential roles; pasif technician, reflective practician, and transformative intelectual is very inportant in Arabic learning in posmethod era. The principle of at-tharîqatu ahammu min al-mâddah (method is more important than content) can be developed to be main principle "spirit, profesionality and strategic role of language educator is more important in teaching Arabic than the method itself", since basically there is no most appropriate and ideal method for any goals and situation of Arabic learning.
\end{abstract}

Keywords : Arabic learning, posmethod era, theacher's role, intelectual transformative

\begin{abstract}
Abstrak
Tulisan ini bertujuan menjawab dua persoalan penting, yaitu: (1) peta perkembangan metodologi pembelajaran bahasa Arab dari dekade 1960-an hingga sekarang yang belum jelas formulasinya, dan (2) pengembangan pembelajaran bahasa Arab di era posmetode dengan mengoptimalkan peran strategis guru dalam proses pembelajaran bahasa Arab. Tulisan ini mengandalkan sumber-sumber bibliografis dari berbagai buku dan artikel di jurnal ilmiah tentang linguistik dan pembelajaran bahasa Arab. Pembacaan data-data pemikiran para akademisi dan pakar bahasa Arab dilakukan dengan pendekatan historis-kritis dan pemaknaan substansinya dengan analisis isi. Konsep B. Kumaravadivelu dalam Beyond Methods: Macrostrategies for Language Teaching (2003) yang menghendaki guru bahasa memainkan tiga peran kunci: sebagai teknisi pasif, praktisi reflektif, dan intelektual transformatif ternyata sangat diperlukan dalam pembelajaran bahasa Arab di era posmetode. Kaidah bahwa at-tharîqatu ahammu min al-mâddah (metode itu lebih penting daripada materi) dapat dikembangkan menjadi prinsip utama bahwa "spirit, profesionalitas dan peran strategis pendidik bahasa itu jauh lebih penting dalam membelajarkan bahasa Arab daripada metode itu sendiri", karena pada dasarnya tidak ada metode yang paling cocok dan paling ideal untuk berbagai tujuan dan situasi pembelajaran bahasa Arab.
\end{abstract}

Kata Kunci : pembelajaran bahasa Arab, era posmetode, peran guru, intelektual transformatif

How to Cite: $\quad$ Abdul Wahab, Muhbib. "PEMBELAJARAN BAHASA ARAB DI ERA POSMETODE" ARABIYAT: Jurnal Pendidikan Bahasa Arab dan Kebahasaaraban [Online], Volume 2 Number 1 (30 Juni 2015)

Permalink/DOI: http://dx.doi.org/10.15408/a.v2i1.1519 


\section{Pendahuluan}

Pembelajaran bahasa asing, khususnya bahasa Inggris, dewasa ini memasuki era baru, yang disebut era posmetode ('ahsr mâ ba'da at-tharîqah). Era ini dianggap sebagai fase baru, hal mana metode tidak lagi dipandang sebagai faktor utama yang menentukan keberhasilan proses pembelajaran bahasa di satu segi, dan di segi lain, guru bahasa diberikan kebebasan dan ruang yang lebih besar untuk menetapkan strategi dan teknik pembelajarannya, tanpa terikat oleh metode tertentu yang asumsi filosofisnya sudah terbangun pada diri guru atau pengajar bahasa sebelum membelajarkan bahasa di dalam kelas.

Menarik dicermati bahwa metodologi pembelajaran bahasa Arab yang ditulis oleh para ulama dan sarjana bahasa Arab, mulai dari al-Muwajjih al-Fannî li Mudarrisî alLughah al-Arabiyyah karya Ibrahim Abdul 'Alim (1968) hingga Tadrîs al-Lughah al'Arabiyyah wafqan li Ahdats al-Tharâ'iq alTarbawiyyah karya 'Alawi Abdullah Thahir (2010), Idhâ'ât li Mu'allimi al-Lughah al-Arabiyyah li Ghair an-Nâthiqîna bihâ karya Abdurrahman bin Ibrahim al-Fauzan (2011), dan Ta'lîm al-Lughah al-'Arabiyyah li Ghair an-Nâthiqîna bihâ karya al-Hafizh Abdurrahim as-Syaikh (2013) tampaknya belum didasarkan pada hasil riset yang serius, memadai, dan komperehensif, melainkan baru didasarkan pada hasil pembacaan, adaptasi, dan kontekstualisasi dari tulisan atau karya-karya yang berkembang di dunia Barat, terutama dalam konteks metodologi pembelajaran bahasa Inggris.

Oleh karena itu, pembahasan tentang metodologi pembelajaran bahasa Arab di era posmetode ini menghendaki penelitian dan diskusi yang intens ditopang oleh pembacaan akademik yang komprehensif dari berbagai perspektif. Misalnya pembelajaran bahasa Arab dari perspektif pedagogis, psikologis, sosiologis, linguistik, sosial politik, antropologi hingga ilmu-ilmu hasil perpaduan seperti: psikolinguistik, sosiolinguistik, neurolinguistik, antropolinguistik, tekstolinguistik, komputolinguistik, antropolinguistik, dan lain sebagainya. Dengan multiperspektif tersebut, metodologi pembelajaran bahasa Arab tidak hanya berkutat pada hirarkiprosedural ala Edward Anthony (1963), yaitu: hirarki pendekatan (approach, madkhal), metode (method, tharîqah), dan teknik (technique, asâlîb ijrâ'iyyah), melainkan metodologi itu bersifat lintas filsafat bahasa, lintas-pendekatan, lintasmetode, lintas-model, lintas-budaya, lintasilmu yang dipandang kompatibel dan kontekstual dengan pembelajaran bahasa Arab mutakhir.

Dalam konteks ini, penulis berpendapat bahwa metodologi pembelajaran bahasa Arab bukan ilmu tunggal, melainkan ilmu majemuk, ilmu hasil per-paduan dan sinergi berbagai disiplin ilmu. Hal ini mengisyaratkan bahwa metodologi pembelajaran bahasa Arab, yang tradisional maupun modern, sangat bergantung pada seberapa jauh pengembang metodologi mampu menyinergikan dan melahirkan "metode-metode baru"1 sesuai dengan

1 Imam Asrori misalnya berupaya mengembangkan strategi pembelajaran bahasa Arab dengan mengacu pada sejumlah teori dalam psikologi dan strategi belajar bahasa. Misalnya saja, dikembangkan strategi memori, strategi kognitif, strategi kompensasi, strategi metakognitif, strategi afektif, strategi sosial, dan strategi komunikasi. Lebih lanjut Asrori juga menawarkan sejumlah strategi dalam mempelajari mufradat, struktur bahasa Arab, dan strategi pengembangan keterampilan berbahasa Arab. Lihat Imam Asrori, Strategi Belajar Bahasa Arab: Teori dan Praktik, (Malang: Misykat, 2011).

Berbasis teori-teori psikolinguistik, Umi Machmudah dan Abdul Wahab Rosyidi juga berupaya merumuskan pembelajaran bahasa Arab dengan 
perkembangan dan tuntutan zaman.

Jika dikaitkan dengan pembelajaran bahasa Arab di Indonesia, metodologi sebagai ilmu tampaknya juga belum mengalami perkembangan yang signifikan. Beberapa buku tentang metodologi yang ditulis oleh para pakar di bidangnya juga memperlihatkan hal sama dengan metodologi pembelajaran bahasa Arab yang ditulis oleh para ulama bahasa Arab dari Negara-negara Timur Tengah. Oleh karena itu, wacana ini setidak-tidaknya menjadi momentum kebangkitan pengembangan metodologi pembelajaran bahasa Arab bagi para peminat dan pemerhati pembelajaran bahasa Arab di Indonesia. Berbagai kajian, riset dan pengembangan (R\&D) perlu digelorakan agar masa depan pendidikan bahasa Arab di Indonesia semakin prospektif dan membahagiakan banyak pihak.

Tulisan ini bertujuan mendiskusikan dan menjawab dua permasalahan penting dan menarik, yaitu: (1) peta perkembangan metodologi pembelajaran bahasa Arab dari dekade 1960-an hingga sekarang yang belum jelas penarasiannya, dan (2) pengembangan pembelajaran bahasa Arab di era posmetode dengan mengoptimalkan peran strategis guru sebagai teknisi pasif, praktisi reflektif, dan intelektual transformatif yang konsepnya dimajukan

menerapkan active learning (at-ta'allum an-nasyith). Dijelaskan bahwa teori-teori pembelajaran seperti Konstruktivisme, Behaviorisme, dan Progresivisme berkontribusi dalam memberikan landasan teoretik pengembangan model pembelajaran bahasa Arab. Karena itu, dikembangkanlah strategi pembelajaran aktif, cooperative learning (at-ta'llum at-ta'âwuni) dengan berbagai ragamnya (Jigsaw, STAD, CIRC, TAI/Team Assisted Individualization, penelitian kelompok, Pakem, dan model-model pembelajaran aktif lainnya disertai pengembangan media pembelajaran bahasa Arab yang relevan untuk active learning. Lihat Umi Machmudah dan Abdul Wahab Rosyidi, Active Learning untuk Pembelajaran Bahasa Arab, Editor: Mujtahid, (Malang: UIN-Malang Press, 2008). oleh B. Kumaravadivelu (2003). Tulisan ini mengandalkan sumber-sumber bibliografis dari berbagai buku dan artikel yang dimuat dalam jurnal ilmiah tentang linguistik dan pembelajaran bahasa Arab. Pembacaan data-data pemikiran para akademisi dan pakar bahasa Arab dilakukan dengan pendekatan historis-kritis dan pemaknaan substansinya dengan analisis isi. Asumsi yang mendasari tulisan ini adalah hasil riset Ahmad Hazratzad \& Mehrnaz Gheitanchian (2010) bahwa untuk dapat menghadapi tantangan abad ke-21, calon guru atau pendidik bahasa (termasuk bahasa Arab) harus dipersiapkan dengan berbekal aneka keterampilan dan teknik yang diperlukan agar dapat memahami perkembangan pendidikan kontemporer dan meraih pengetahuan linguistik dan kultural yang ekstensif, sehingga rasa percaya diri tinggi dalam memainkan perannya sebagai guru dalam kelas bahasa yang berorientasi komunikasi. ${ }^{2}$ Pembelajaran bahasa Arab di era posmetode menghendaki optimalisasi peran guru secara lebih kompleks dan profesional. $^{3}$

2 Ahmad Hazratzad \& Mehrnaz Gheitanchian, "EFL Teachers' Attitudestowards Post-method Pedagogy and Their Students' Achievement", dalam Proceedings of the 10th METU ELT Convention, 2010, h. 6.

3 Perdebatan mengenai metode dan posmetode merupakan perdebatan yang belum sepenuhnya selesai, karena perspektif yang digunakan dalam memahami dan mendefinisikan "metode" berbeda-beda. Era metode dan era posmetode bukan merupakan dua hal yang saling berhadap-hadapan secara kontradiktif. Era posmetode sejatinya merupakan perkembangan lanjutan dari "era metode" yang menjadikan metode sebagai "pintu masuk" menuju sebuah pendekatan, strategi, dan teknik operasional pembelajaran bahasa di dalam kelas.

Posmetode secara konseputual juga tidak dapat dipisahkan dari perspektif yang digunakan untuk memahami hakikat metode itu sendiri. Menurut riset David M. Bell dalam TESOL QUARTERLY, metode sekurang-kurangnya dapat dipahami dalam tiga definisi yang berbeda. Pertama, metode itu meliputi program, kurikulum, prosedur, moda 


\section{Peta Perkembangan Metodologi Pembelajaran Bahasa Arab}

Perkembangan metodologi pembelajaran bahasa Arab mengalami keterlambatan kurang lebih dua dasawarsa dibandingkan dengan metodologi pembelajaran bahasa Inggris. Hal ini, antara lain, disebabkan oleh terlambatnya para sarjana bahasa Arab, khususnya ulama Arab, dalam menekuni dan mengembangkan ilmu metode (metodologi). Para ulama yang menulis karya di bidang metodologi bahasa Arab, pada umumnya, adalah sarjana lulusan Barat, sebut saja misalnya: Rusydi Ahmad Thu'aimah, Ali Ahmad Madkur, Fathi Ali Yunus, Abdul 'Aziz Ibrahim al-Ushaili, Abdurrahman ibn Ibrahim al-Fauzan, Muhammad al-Awraghi, dan sebagainya.

Buku-buku tentang metodologi pembelajaran bahasa Arab baru ditulis penghujung 1970-an. Buku pertama yang membahas metode pembelajaran bahasa Arab adalah al-Muwajjih al-Fannî li Mudarrisî al-Lughah al-Arabiyyah (1968) karya Abdul 'Alim Ibrahim. Dalam buku ini antara lain dijelaskan dua teori tentang sistem pembelajaran bahasa Arab, yaitu nazhariyat al-wahdah (all in one system, pembelajaran dengan sistem terpadu) dan nazhariyat al-furû' (teori pembelajaran dengan pemisahan/pencabangan unsurunsur bahasa Arab). Dalam buku ini belum presentasi, temuan-temuan riset, tes, media, film, teks, materi pelajaran, dan sebagainya. Kedua, metode merupakan mixed set of classroom practice, atau sejumlah prosedur yang harus dilalui pendidik dalam memberi layanan pembelajaran bahasa. Ketiga, metode merupakan paying yang mencakup pendekatan, desain, dan prosedur. Atas dasar pemahaman terhadap sejumlah definisi metode dan perkembangan yang terjadi, maka posmetodologi dipahami sebagai sintesis terhadap sejumlah metode di bawah payung method redefining condition atau CLT (Communicative Language Teaching). Lihat David M. Bell, "Method and Postmethod: Are They Really so Incompatible?" dalam TESOL Quarterly, Vol. 37, No. 2, Summber 2003, h. 326-27. dijelaskan sejumlah metode pembelajaran bahasa Arab yang kita kenal sekarang (Qawâ'idwatarjamah,mubâsyirah,sam'iyyah syafawiyyah, qirâ'ah, dan sebagainya). Buku ini juga menjelaskan pembelajaran qirâ'ah, ta'bîr, imlâ', qawâ'id nahwiyyah, adab (sastra), pendidikan agama, kaligrafi Arab (khath 'Arabî), dan media pembelajaran bahasa Arab. ${ }^{4}$ Penulis buku ini tampaknya juga belum tegas mengkhususkan apakah buku ini untuk guru penutur bahasa Arab asli atau penutur asing.

Pada 1970-an dan 1980-an mulai bermunculan beberapa buku bahasa Arab tentang metodologi pengajaran bahasa Arab. Misalnya saja, buku Thuruq Ta'lîm al-Lughah al-Arabiyyah (1985) karya Muhammad Abdul Qadir Ahmad. Karya-karya tentang pembelajaran bahasa Arab mulai didasari riset yang relatif mendalam. Pada 1978 misalnya, Fathi Ali Yunus menerbitkan hasil risetnya berjudul Tashmîm Manhaj Ta'lîm al-Lughah al-Arabiyyah li al-Ajânib. Riset eksperimen (bahts tajrîbî) yang disponsori dan dilakukan di University of Minnesota USA ini juga mulai difokuskan pada penutur asing (non-Arab). Masalah yang diteliti dalam riset ini adalah "Tujuan pembelajaran apakah yang seyogyanya dilakukan pada tingkat pertama pengajaran bahasa Arab bagi penutur asing?" "Apa faktor-faktor penyebab penutur asing mempelajari bahasa Arab sebagai bahasa asing?" "Situasi

4 Baca Abdul 'Alim Ibrahim, al-Muwajjih alFannî li Mudarrisî al-Lughah al-Arabiyyah, (Kairo: Dâr al-Ma'ârif, 1978), Cet. ke-10. Sebelum tahun 1968, sebenarnya kajian tentang bahasa Arab sudah dilakukan secara akademik, namun belum membahas secara detail tentang metodologi pengajaran bahasa Arab. Permasalahan pembelajaran bahasa Arab berikut klasifikasi tingkatan pembelajaran bahasa Arab (marhalah ibtidâiyyah, mutawassithah dan mutaqaddimah) untuk non-Arab (penutur asing) mulai dikaji, misalnya oleh Ali al-Hadidi. Lihat Ali al-Hadidi, Musykilât Ta'lîm al-Lughah al-'Arabiyyah li ghair al-Arab, (Kairo: Dâr al-Kâtib al-'Arabi, 1966). 
seperti apakah yang memungkinkan digunakannya bahasa Arab sebagai bahasa asing?"5 Riset ini menyimpulkan bahwa tujuan pembelajaran bahasa Arab pada umumnya adalah untuk menguasai empat keterampilan berbahasa (istimâ', kalâm, qirâah, dan kitâbah). Sedangkan faktor penyebab penuturasing mempelajaribahasa Arab adalah untuk membaca (memahami) budaya Arab dan memperluas cakrawala pemikiran dan melakukan perjalanan wisata ke Negara-negara Arab. Karena riset ini diorientasikan kepada desain kurikulum pembelajaran bahasa Arab, maka tujuan dan faktor tersebut menjadi landasan untuk pengembangan silabus pembelajaran bahasa Arab untuk keempat keterampilan tersebut. $^{6}$

Dalam dekade ini terbit pula sebuah buku bahasa Arab tentang metodologi pembelajaran bahasa Arab yang menyinergikan beberapa perspektif disiplin ilmu: linguistik (teori-teori linguistik), psikologi (teori belajar), dan sosiologi (teori kompetensi komunikasi). Buku dimaksud adalah al-Lughat al-Ajnabiyyah: Ta'lîmuhâ wa Ta'allumuhâ (1988). Pembelajaran bahasa asing dalam buku ini tidak hanya difokuskan pada metodologinya, melainkan juga pada kurikulum pengajarannya. Dalam buku ini mulai dibedakan antara metodologi pembelajaran bahasa asing tradisional (tharîqah al-qawâ'id wa attarjamah) dan metode pembelajaran bahasa asing modern yang meliputi: (1) at-tharîqah al-tarkîbiyyah/al-binyawiyyah (metode struktural), (2) at-tharîqah attawâshuliyyah (metode komunikatif), dan (3) at-tharîqah al-'amaliyyah (metode

$5 \quad$ Fathi Ali Yunus, Tashmîm Manhaj Ta'lîm al-Lughah al-'Arabiyyah li al-Ajânib (Bahts Tajrîbî), (Kairo: Dâr al-Tsaqâfah, 1978), h. 11

Fathi Ali Yunus, Tashmîm Manhaj Ta'lîm alLughah al-'Arabiyyah ..., h. 257-262. praktik-pragmatik). Metode yang terakhir tidak sama dengan metode eklektik (attharîqah al-intiqâ'iyyah), karena metode yang terakhir cenderung mengambil aspekaspek positif (keunggulan, kelebihan) dari beberapa metode dan memadukannya dalam waktu yang sama, sedangkan metode praktik-pragmatik cenderung mengedepankan metode tertentu yang dinilai praktis dan relevan dengan tujuan pembelajaran bahasa. $^{7}$

Metode qawâ'id dan tarjamah yang sudah "merajai" dunia pembelajaran bahasa Arab sejak abad ke-19 itu dan dinilai "tidak berhasil" mengantarkan pebelajar bahasa mampu berkomunikasi dengan bahasa yang dipelajarinya secara efektif itu kemudian memunculkan reaksi kritis dari sejumlah ahli, sehingga muncullah metode langsung (direct method, at-tharîqah al-mubâsyirah). Bersamaan dengan itu, tepatnya di awal abad ke-20, muncul pula metode reformasi (attharîqah al-Islâhiyyah, reform method) yang tidak hanya bertujuan untuk memahirkan keterampilan berbicara dalam belajar bahasa asing, melainkan juga mengantarkan peserta didik mampu berkomunikasi melalui tulisan (kompetensi menulis). "Kekecewaan" terhadap metode tradisional pun terus berlanjut, sehingga pada 19301940-an muncul pula metode yang lebih menitikberatkan kepada pengembangan keterampilan membaca, yaitu tharîqah alqirâ'ah. Setelah Perang Dunia ke-2, tepatnya pada 1940-1950-an, muncul pula metode audio lingual atau metode dengar ucap (attharîqah as-sam'iyyah as-syafawiyyah) yang strukturalis sekaligus behavioristik yang cenderung mekanistik. $^{8}$

$7 \quad$ Nayif Khurma dan Ali Hajjaj, al-Lughat alAjnabiyyah: Ta'limuha wa Ta'allumuha, (al-Kuwait: 'Âlam al-Ma'rifah, 1988), h.152-153.

8 Nayif Khurma dan 'Ali Hajjaj, al-Lughat alAjnabiyyah: Ta'lîmuhâ wa Ta'allumuhâ..., h. 160-163. 
Dominasi metode yang terakhir (audio lingual) pada dekade 1940-1950-an mendorong perlunya evaluasi terhadap kelemahan metode ini yang cenderung bernuansa "dehumanisasi" pesertadidikdan belajar bahasa asing tidak dalam suasana alami (artifisial) dan nyata (realistik). Caroll JB. dan Chastain K. misalnya mengkritisi perlunya penjelasan gramatika sebelum dilakukan drills (tadrîbât) terhadap pola-pola bahasa (anmâth lughawiyyah), membaca, diskusi, dan menulis. Selain itu, pembelajaran bahasa juga perlu didasarkan pada situasi nyata dan konten kebahasaan yang mendekati penggunnaan bahasa yang sesungguhnya dalam realitas kehidupan. Karena pada akhirnya tidak ada metode yang paling baik, maka dimunculkannya metode eklektik (tharîqah intiqâ'iyyah) sebagai alternatif untuk mengatasi berbagai kelemahan metode yang ada dengan memadukan sejumlah kelebihan metode itu. Untuk mengatasi "dehumanisasi" atau "mekanisasi" yang ada pada metode audio lingual, dikembangkanlah metode komunikatif (at-tharîqah at-tawâshuliyyah) yang bertujuan untuk mengembalikan fungsi utama bahasa sebagai media komunikasi. Pembelajaran bahasa asing harus berorientasi kepada pengembangan komptensi komunikasi dalam situasi nyata dan untuk berbagai tujuan. Metode ini juga mendapat afirmasi teoretik dari aliran kognitivisme yang dikembangkan oleh Noam Chomsky bahwa setiap manusia memiliki LAD (Language Acquisition Device, jihâz iktisâb al-lughah), kompetensi berbahasa (berkomunikasi) dan gramatika universal (universal grammar, al-qawâ'id alkulliyyah). Pembelajaran bahasa bertujuan untuk mengaktualisasikan kompetensi itu menjadi performansi berbahasa dalam berkomunikasi. Namun demikian, metode komunikatif juga dikritisi, dievaluasi, dan dimodifikasi lebih lanjut. Dari perspektif emosional, dikembangkanlah metode diam (at-tharîqah al-shâmitah, silent way) untuk memberi kesempatan yang seluas mungkin bagi peserta didik agar berkomunikasi satu samalain, sehingga guru lebih banyak "diam", tidak mendominasi pembicaran. Setelah itu, muncul pula metode natural (at-tharîqah at-thabî'iyyah), metode sugestopedia (at-tharîqah al-îha'iyyah) dan metode community language learning (tharîqah ta'allum al-lughah fi al-mujtama'). ${ }^{9}$

Di penghujung 1980-an, tepatnya pada 1989 terbitlah Ta'lîm al-'Arabiyyah li Ghair an-Nâthiqîna biha: Manâhijuhu wa Asâlibu karya Rusydi Ahmad Thu'aimah. Buku ini merupakan buku yang dinilai paling otoritatif tentang metodologi pengajaran bahasa Arab, karena tidak hanya membahas pendekatan dan metode pengajaran bahasa Arab sebagaimana diulas oleh Nayif Khurma dan 'Ali Hajjaj, melainkan juga membahas prinsip-prinsip penyusunan dan pengembangan kurikulum pembelajaran bahasa Arab berikut ragam kurikulumnya, teknik pembelajaran empat keterampilan bahasa, unsur-unsur bahasa (mufradât, nahwu-sharaf, dan sastra), berikut teknik pengembangan latihan-latihan berbahasa, sampai kepada pengembangan tes bahasa, dan pengajaran bahasa Arab untuk tujuan khusus (tadrîs al-'Arabiyyah li Aghrâdh Khâshshah). ${ }^{10}$

Sebelum menyusun buku tersebut, bersama Mahmud Kamil an-Naqah, Rusydi Ahmad Thu'aimah juga melakukan riset mengenai penyusunan, analisis, dan evaluasi buku ajar bahasa Arab bagi penutur

\footnotetext{
9 Nayif Khurma dan 'Ali Hajjaj, al-Lughat alAjnabiyyah..., h. 166-174.

10 Baca Rusydi Ahmad Thu'aimah, Ta'lîm alLughah al-Arabiyyah li Ghair an-Nâthiqîna bihâ: Manâhijuhu wa Asâlîbuhu, (Rabath: ISESCO, 1989).
} 
asing. Hasil riset ini diterbitkan oleh Jami'ah Umm al-Qura di Mekkah pada 1983 dengan judul al-Kitâb al-Asâsi li Ta'lîm al-Lughah al'Arabiyyah li an-Nâthiqîna bi Lughât Ukhrâ. Dalam penyusunan materi ajar dan buku bahasa Arab, keduanya memperkenalkan dan mengelaborasi beberapa prinsip: psikologis, kultural, edukasional, dan linguistik. Selain itu, orientasi penyajian, bahasa buku, dan metode pembelajarannya juga dibahas. ${ }^{11}$

Di era 1980-an karya tentang pembelajaran bahasa Arab terkadang "disandingkan" dengan pendidikan agama, seperti Asâsiyyât Ta'lîm al-Lughah al'Arabiyyah wa at-Tarbiyah ad-Dîniyyah karya Fathi Ali Yunus, Mahmud Kamil anNaqah, dan Ali Ahmad Madkur. Pembahasan dalam buku ini tidak mengelaborasi sama sekali metodologi pembelajaran bahasa Arab secara umum, melainkan langsung menjelaskan metode atau teknik pembelajaran empat keterampilan bahasa, pembelajaran sastra dan balâghah dan pembelajaran qawâ'id, dan diakhiri dengan pembelajaran pendidikan agama Islam. ${ }^{12}$ Buku yang substansinya kurang lebih sama dan juga terbit di era 1980-an adalah Thuruq Tadrîs al-Lughah al-Arabiyyah karya Jaudat ar-Rukkabi ${ }^{13}$, Thuruq Tadrîs al-Lughah al'Arabiyyah karya Zakariya Ibrahim, dan juga buku Thuruq Tadrîs al-Lughah al-Arabiyyah wa at-Tarbiyah ad-Dîniyyah fi Dhaui al-

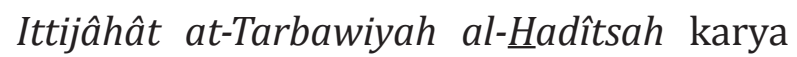
Mahmud Rusydi Khathir, Yusuf al-Hamadi,

11 Baca Rusydi Ahmad Thu'aimah dan Muhammad Kamil an-Naqah, al-Kitâb al-Asâsi li Ta'lîm al-Lughah al-'Arabiyyah li an-Nâthiqâna bi Lughat Ukhrâ: I'dâduhu, Tahliluhu-Taqwîmuhu, (Mekkah: Jâmi'ah Umm al-Qura, 1983).

12 Fathi Ali Yunus, dkk, Asâsiyyât Ta'lîm alLughah al-'Arabiyyah wa at-Tarbiyah ad-Dîniyyah, (Kairo: Dâr as-Tsaqâfah, 1984).

13 Baca Jaudat ar-Rukkabi, Thuruq Tadrîs al-Lughah al-Arabiyyah, (Damaskus: Dâr al-Fikr, 1986).
Muhammad Izzat 'Abdul Maujud, dan Rusydi Ahmad Thu'aimah. ${ }^{14}$ Teknik pembelajaran bahasa Arab secara rinci dan detail juga dapat dijumpai dalam buku Asâlib Tadrîs al-Lughah al-'Arabiyyah karya Muhammad 'Ali al-Khouli. Pembahasan metodologi pembelajaran bahasa Arab pada dekade 1980-an sebagian besar telah dipengaruhi oleh buku-buku serupa yang terbit di Barat, dan sebagian besar penulisnya memang pernah mengenyam pendidikan di Barat, khususnya di Amerika Serikat.

Pada dekade 1990-an dan 2000-an, perkembangan metodologi pembelajaran bahasa Arab di dunia Islam, khususnya di Negara-negara Arab dan Indonesia tidak jauh berbeda perkembangan yang terjadi pada dekade sebelumnya. Hanya saja, pembahasan tentang metodologi pembelajaran bahasa Arab cenderung difokuskan pada empat keterampilan bahasa. Misalnya saja, al-Mahârat alLughawiyyah: madkhal ila Khashâish alLughah al-Arabiyyah wa Funûniha karya Muhammad Shalih as-Syanthi dan Tadrîs Funûn al-Lughah al-Arabiyyah karya Ali Ahmad Madkur. Selain itu, pada dekade ini mulai ada upaya untuk mengenalkan teoriteori yang melandasi pembelajaran bahasa Arab, baikmelaluipenerjemahan daribahasa Inggris ke dalam bahasa Arab maupun penulisan karya langsung. Buku Principles of Language Learning and Teaching karya H. Douglas Brown misalnya diterjemahkan ke dalam bahasa Arab oleh 'Abduh arRajihi dan Ali Ali Ahmad Sya'ban, Usus Ta'allum al-Lughah wa Ta'limuha (1994). Sementara itu, buku Brown tersebut baru diterjemahkan ke dalam bahasa Indonesia pada 2007 dan diterbitkan oleh Kedubes

14 Baca Mahmud Rusydi Khathir, dkk., Thuruq Tadrîs al-Lughah al-Arabiyyah wa at-Tarbiyah adDîniyyah fi Dhaui al-Ittijâhât at-Tarbawiyyah alHadîtsah, (Kairo: Dâr al-Ma'rifah, 1983). 
Amerika di Jakarta. ${ }^{15}$ Pada 1998, 'Abduh arRajihi juga menulis buku 'Ilm al-Lughah atTathbîqi wa Ta'lîm al-'Arabiyyah dan pada 1999 Abdul Aziz Ibrahim al-Ushaili juga menulis an-Nazhariyyât al-Lughawiyyah wa an-Nafsiyyah wa Ta'lîm al-Lughah alArabiyyah.

Selain itu, pada dekade 2000-an pembelajaran bahasa Arab lebih dirinci peruntukannya. Buku Fushûl fi Tadrîs alLughah al-'Arabiyyah (Ibtidâ'i-MutawassithTsânawi) karya Hasan Ja'far al-Khalifah (2003) memilah peruntukan pembelajaran bahasa Arab untuk tingkatan/jenjang pendidikan. Selain itu, mulai dibahas pula pengembangan aktivitas kebahasaan di luar kelas dan penyiapan berikut pelatihan calon guru bahasa Arab. ${ }^{16}$ Dengan topik bahasan yang kurang lebih sama, namun berbeda dari segi konten dan analisisnya, Rusydi Ahmad Thu'aimah dan Muhammad as-Sayyid Manna' juga menulis buku Tadrîs al-'Arabiyyah fi at-Ta'lîm al-Âmm: Nazhariyyat wa Tajârib, yang dikhususkan untuk pembelajaran bahasa Arab dalam pendidikan umum, dan juga menulis Ta'lîm al-'Arabiyyah wa ad-Dîn Baina al-'Ilm wa alFanni yang diperkaya dengan pembahasan media pembelajaran bahasa Arab dan aktivitas kebahasaan yang menunjang proses pembelajaran bahasa Arab seperti: radio sekolah, koran sekolah, klub bahasa

15 Baca Douglas Brown, Prinsip Pembelajaran dan Pengajaran Bahasa, Terjemahan Noor Cholis dan Yusi Avianto Parianom, Edisi Kelima, (Jakarta: Kedubes Amerika Serikat, 2007). Saat ini sudah terbit untuk edisi keenam dalam bahasa Inggris, dan oleh Amazon dijual secara online dengan harga USD \$63.44.

16 Selain topik tersebut al-Khalifah juga merinci dan memasukkan pembelajaran imlâ', pembelajaran kaligrafi Arab, pembelajaran sastra, pembelajaran balaghâh, di samping pembelajaran empat keterampilan bahasa. Lihat Hasan Ja'far alKhalifah, Fushûl fi Tadrîs al-Lughah al-'Arabiyyah (Ibtidâ'i-Mutawassith-Tsânawi), (Riyadh: Maktabah ar-Rusyd, 2003), Cet. II.
Arab, komunitas pecinta sastra, majalah dinding, dan sebagainya. ${ }^{17}$

Pengembangan metodologi pembelajaran bahasa Arab, sejauh ini, tampaknya hanya terjadi pada pembelajaran konten, unsur-unsur bahasa dan keterampilan bahasa, tetapi tidak pada metodenya itu sendiri. Ada kecenderungan perluasan pembelajaran materi kebahasaaraban disertai dengan penguatan teori-teori dan aplikasi-aplikasi praktis. Misalnya saja, buku Tadrîs al-Lughah al-Arabiyyah: Mafâhîm Nazhariyyah wa Tathbîqât 'Amaliyyah karya Walid Ahmad Jabir yang menambahkan pembelajaran lagu dan mahfuzhât dalam sistem pembelajaran bahasa Arab. ${ }^{18}$ Kecenderungan yang sama juga terjadi di Indonesia. Buku Metodologi Pengajaran Bahasa Arab (2005) karya Ahmad Fuad Effendy juga menunjukkan adanya metode baru dalam pembelajaran bahasa Arab. Buku terakhir memperluas bahasannya dikaitkan dengan kurikulum berbasis kompetensi, pembelajaran kontekstual, pembelajaran quantum komunikatif, dan penciptaan lingkungan pembelajaran bahasa Arab, disertai format silabus, skenario pembelajaran dan profil pembelajaran bahasa Arab. ${ }^{19}$

Hingga terbitnya Ahdats al-Ittijâhât fi Ta'lîm wa Ta'allum al-Lughah al-'Arabiyyah (2008) karya Khalid Mahmud Muhammad Irfan, al-Ittijâhât al- $\underline{\text { Hadîtsah }}$ fi Tadrîs al-Lughah al-Arabiyyah: al-Usus wa atTathbîqât (2012) karya Huda Muhammad Imam Shalih dan Muhammad 'Abdul Aziz ar-

17 Baca Rusydi Ahmad Thu'aimah dan Muhammad as-Sayyid Manna', Tadrîs al-'Arabiyyah fi at-Ta'lîm al-'Âmm dan Ta'lîm al-'Arabiyyah wa ad-Dîn, (Kairo: Dâr al-Fikr al-'Arabî, 2000).

18 Baca Walid Ahmad Jabir, Tadrîs al-Lughah al-'Arabiyyah: Mafâhîm Nazhariyyah wa Tathbîqât 'Amaliyyah, ('Amman: Dâr al-Fikr, 2002), Cet. I.

19 Baca Ahmad Fuad Effendy, Metodologi Pembelajaran Bahasa Arab, (Malang: Misykat, 2005). 
Rab'i, Asâlîb wa Thuruq Tadrîs al-Lughah al'Arabiyyah wa I'dâd Durûsihâ al-Yaumiyyah (2007) karya Fuad Hasan Abu al-Haija', alLisâniyyah an-Nisbiyyah wa Ta'lîm al-Lughah al-Arabiyyah (2010) karya Muhammad alAuraghi, dan Idhâ'at li Mu'allimi al-Lughah al-Arabiyyah li Ghair an-Nâthiqîna bihâ (2011) karya Abdurrahman ibn Ibrahim al-Fauzan, belum ditemukan (muncul) metode mutakhir di bidang pembelajaran bahasa Arab. Kalau pun ada perkembangan baru, hanyalah aplikasi sejumlah model pembelajaran aktif dan aplikasi teori konstruktivisme dalam pembelajaran bahasa Arab seperti an-nazhariyyah alBina'iyyah wa Tathbiquha fi Tadris al-Lughah al-Arabiyyah: Istirâtijiyyah at-Tadrîs alHadîtsah wa Namâdzij li at-Taqwîm al-Binâ'i (2013) karya Munif Hudhair ad-Dhawi ${ }^{20}$. Dengan demikian, dapat ditegaskan bahwa perkembangan metodologi pembelajaran bahasa asing, khususnya bahasa Arab, memang memasuki era baru, yang disebut dengan era posmetode. Jadi, paradigma yang perlu dikembangkan oleh pakar maupun praktisi pembelajaran bahasa Arab adalah bahwa pembelajaran bahasa Arab

20 Dalam buku yang disebut terakhir, dijela kan bahwa pembelajaran bahasa -mengutip Meril dan Jones-perlu didasarkan pada sejumlah asumsi: (1) pembelajaran konstruktif (at-ta'allum al-binâ'i) bahwa pengetahuan, termasuk bahasa, itu dibangun melalui pengalaman, sedangkan belajar itu merupakan proses konstruktf; (2) penafsiran personal (attafsîr as-syakhsî), bahwa belajar itu hasil penafsiran personal di pebelajar terhadap pengalaman yang diperolehnya; (3) belajar itu merupakan proses aktif (at-ta'allum 'amaliyyah nasyithah) yang bermakna dan menumbuhkan makna berdasarkan pengalaman belajar itu sendiri; (4) belajar juga merupakan proses kooperatif (kerjasama); (5) belajar harus terjadi dalam lingkungan yang nyata (bî'ah wâqi'iyyah); dan (6) tes terpadu (takâmul al-ikhtibârât) terhadap proses pembelajaran. Lihat Munif Hudhair ad-Dhawi, an-Nazhariyyah al-Binâ'iyyah wa Tathbîquhâ fi Tadrîs al-Lughah al-Arabiyyah: Istirâtîjiyyah at-Tadris alHadîtsah wa Namâdzij li at-Taqwîm al-Binâ̂î, (Riyadh: Mathâbi' al-Humaidhi, 2013), h. 29. itu menghendaki kompetensi mumpuni (profesional) guru dalam melakukan sintesis terhadap sejumlah metode dan media, sehingga performa pembelajaran bahasa Arab dapat lebih dioptimalkan.

\section{Peran Guru Bahasa Arab di Era Posmetode}

Menurut Jack J. Richads (1990) dan Kumaravadevelu (2001), pembelajaran bahasa kini telah memasuki era baru, yaitu era posmetode (post methods, 'ashr ma ba'da al-tharîqah). Era metode dianggap "telah selesai" dan era pembelajaran bahasa kini bergerak "melampaui metode" (beyond methods) menuju kondisi posmetode (postmethod condition). ${ }^{21}$ Era baru ini, antara lain, ditandai dengan reduksi peran dan fungsi metode dalam pembelajaran bahasa. Pemeran utama dalam pembelajaran bahasa adalah guru dan peserta didik. Era ini tampaknya hendak menggugurkan "kaidah edukasi": at-Tharîqatu ahammu min almâddah (metode itu lebih penting daripada materi itu sendiri), dan mengganti dengan kaidah baru: al-mudarris al-mu'ahhal ahammu wa aktsaru ta'tsîran fi ta'lim allughah al-'arabiyyah min at-tharîqah (Guru yang professional itu lebih penting dan lebih berpengaruh pada pembelajaran bahasa Arab daripada metode). Bahkan spirit dan kompetensi guru (ruh al-mudarris wa kafa'atuhu) itu jauh lebih penting dan berperan.

Selama kurang lebih tiga dekade, metode pengajaran bahasa didominasi oleh konsep Anthony (1970) dengan hirarki metodologisnya: approach, method, and technique (dengan metode sebagai payungnya). Setelah metode

21 LihatDavid M. Bell, "Methodand Postmethod: Are They Really so incompatible?", dalam TESOL QUARTERLY Vol. 37, No. 2, Summer 2003, h. 325. 
eklektik menjadi solusi terhadap berbagai kekurangan dan keterbatasan berbagai metode yang ada (gramatika dan terjamah, langsung, audiolingual, natural, membaca, komunikatif, dan sebagainya), dimunculkan pemikiran bahwa sesungguhnya pembelajaran bahasa tidak harus terikat pada metode "konvensional", lebih-lebih kemunculan masing-masing metode itu -dalam sejarah perkembangannyaselalu mendapat reaksi dan kritikan dari pengritiknya di kemudian hari. Metode audiolingual direspons dan "ditandingi" oleh munculnya silent way (metode diam), sugestopedia (at-tharîqah al-îha'iyyah), dan respons fisik total (Total Physical Response). ${ }^{22}$

Pendidik atau guru bahasa di era posmetode tidak hanya memainkan peran sebagai pengguna metode, melainkan juga harus mengamati, memotivasi, meneliti (termasuk penelitian tindakan kelas), mengelola, mendayagunakan multimedia dan multikecerdasan peserta didik, menciptakan lingkungan kondusif dan sekaligus mengevaluasi keseluruhan proses (rencana, strategi, materi, interaksi pembelajaran, kompetensi, relevansi, dan sebagainya) dalam rangka mencapai tujuan pembelajaran bahasa yang diharapkan. Dengan kata lain, guru bahasa memainkan peran sangat strategis dan menentukan keberhasilan proses pembelajaran bahasa Arab.

Jika proses pembelajaran bahasa "terpaku" pada penerapan metode, maka yang terjadi kemudian adalah guru/dosen yang mengajar dengan menggunakan

22 Mengenai metode pengajaran bahasa yang terinspirasi usia dan pemerolehan, lihat $\mathrm{H}$. Douglas Brown, Prinsip Pembelajaran dan Pengajaran Bahasa, terjemahan dari The Principles of Language Teaching oleh Noor Cholis dan Yusi Avianto Pareanom, (Jakarta: Kedubes Amerika Serikat, 2008), h. 84-85. metode tertentu menjadi "dipaksa" terikat dengan metode itu. Akibatnya, improvisasi, kreativitas, dan spontanitas dalam proses pembelajaran bahasa tidakmuncul dan tidak berkembang. Seiring dengan itu, teori-teori baru berkaitan dengan kecerdasan majemuk, pemrograman neurolinguistik, pengajaran berbasis tugas dan/atau masalah, dan sebagainya bermunculan, di samping adanya kecenderungan pemaduan atau sinergi berbagai metode menjadi metode eklektik. Apakah masih ada ruang (tempat) bagi metode dalam pembelajaran bahasa di abad ke-21, tepatnya di era posmetode ini (the postmethod era)?

Jun Liu (2004) dari Universitas Arizona mencoba menjawab pertanyaan tersebut dengan melakukan sebuah survey internasional (1999) dengan mengambil sampel 800 guru bahasa Inggris yang sampelnya ditentukan secara acak (random sampling) dari 17.800 guru di berbagai belahan dunia. Di antara kesimpulannya adalah bahwa pendekatan komunikatif dan metode eklektik merupakan dua metode (dari sekian banyak metode pembelajaran bahasa) yang paling tinggi tingkat familiaritas, preferensi, dan penggunaannya. Jika berbagai faktor dipertimbangkan dalam pembelajaran bahasa, seperti: konteks pembelajaran, instructional setting, tingkat kemampuan siswa, ukuran kelas, latar belakang pendidikan dan pengalaman guru, dan status native speaker tidaknya guru, maka berbagai pola dan model pembelajaran bahasa muncul, misalnya model pembelajaran kontekstual, tematik, kooperatif, kolaboratif, pembelajaran bahasa berbasis multikecerdasan, dan sebagainya. Selain itu, dalam kelas yang ukurannya lebih besar dengan tingkat kemampuan siswa yang relatif masih 
rendah, metode gramatika dan terjemah juga masih dipergunakan. ${ }^{23}$ Dengan kata lain, di era posmetode, metode tidak sepenuhnya ditinggalkan, tetapi masih dipergunakan dengan mempertimbangkan berbagai faktor dan variabel yang memungkinkan proses pembelajaran bahasa itu berlangsung efektif dan membuahkan hasil yang fungsional dan optimal. Namun demikian, peran guru bahasa menjadi sangat penting, dan karena itu, proses penyiapan dan pendidikan guru bahasa secara professional mutlak dilakukan sesuai dengan standar komptensi yang diharapkan.

Dalam buku Beyond Methods: Macrostrategies for Language Teaching, B. Kumaravadivelu, menjelaskan sejumlah strategi makro pembelajaran bahasa di era posmetode. Di antaranya adalah perlunya konseptualisasi aktivitas mengajar dan membelajarkan bahasa, karena mengajar dan membelajarkan itu merupakan perpaduan antara ilmu dan seni. Dalam konteks ini, guru bahasa harus memainkan tiga peran strategis, yaitu: guru sebagai teknisi pasif, guru sebagai praktisi reflektif, dan guru sebagai intelektual transformatif ${ }^{24}$. Selain itu, strategi pembelajaran bahasa yang perlu dikembangkan adalah mengoptimalkan kesempatan (peluang) belajar, meminimalisasi ketidaksinkronan perseptual, memahami pedagogi di era posmetode, memfasilitasi interaksi dalam belajar, kontekstualisasi masukan linguistik, mengintegrasikan pengembangan empat keterampilan bahasa, menjamin relevansi

23 Lihat Jun Liu, "Methods in the Post-Methods Era: Report on an International Survey on Language Teaching Methods", dalam IJES (International Journal of English Studies), Vol. 4 (4), 2004, h. 137.

24 Uraian lebih lanjut, lihat Kumaravadivelu, Beyond Methods: Macrostrategies for Language Teaching, (Yale: Yale University Press, 2003), h. 22. sosial, dan menumbuhkan kesadaran budaya yang terkait dengan bahasa.

Oleh karena itu, peran guru dalam pembelajaran bahasa Arab sangat ditentukan oleh penguasaan kompetensi guru itu sendiri, baik kompetensi profesional, pedagogik, sosial, maupun personal (kepribadian). Hasil penelitian Jill Murray (Macquarie University) menunjukkan bahwa pembelajaran bahasa berbasis kompetensi dapat diperankan oleh guru dengan menguasai tujuh elemen penting kompetensi, yaitu: (1) memahami isi materi ajar dan mengetahui bagaimana mengajarkan konten itu kepada siswa, (2) memahami siswa-siswi mereka dan mengetahui bagaimana mereka belajar, (3) merencanakan, menilai, dan melaporkan pembelajaran yang efektif, (4) berkomunikasi secara efektif dengan siswa, (5) berkreasi dan menjaga kenyamanan dan lingkungan belajar yang menantang melalui pendayagunaan keterampilan memanaj kelas, (6) meningkatkan profesionalitas dan praktikabilitas secara terus-menerus, dan (7) menjadi anggota asosiasi profesi dan terlibat secara aktif dalam komunitas yang lebih luas. ${ }^{25}$ Dengan tujuh elemen kompetensi tersebut, peran guru bahasa tidak hanya sekadar menjadi agen transfer of knowledge, melainkan sebagai pengembang lingkungan berbahasa, peneliti, dan aktivis dalam komunitas atau asosiosi profesi bidang ilmu yang ditekuninya, sehingga selalu mengikuti perkembangan ilmu dan memutakhirkan isu-isu kebahasaaraban yang digelutinya.

25 Jill Murray, "Teacher competencies in the post-method landscape: The limits of competencybased training in TESOL teacher education", dalam Australian and New Zealand Journal of Vocational Education Research, 2009 Volume 24 No 1, h. 19. 


\section{Pengembangan Pembelajaran Bahasa Arab di Era Posmetode}

Selama ini diasumsikan bahwa pembelajaran dan pengajaran bahasa yang ideal (efisien dan efektif) menghendaki penggunaan metode dan media yang memungkinkan peserta didik dapat mencapai tujuan yang ditetapkan. Asumsi ini tidak sepenuhnya salah, namun ketergantungan kepada metode dan media bukanlah faktor penentu utama keberhasilan pengajaran dan pembelajaran bahasa Arab. Di era posmetode ini, banyak hal telah berubah dan menuntut guru proaktif dan kreatif dalam mencari dan menemukan strategi dan pendekatan yang tepat, sesuai dengan tujuan pembelajaran bahasa Arab dan kebutuhan peserta didik. Era posmetode ini ditandai oleh ditinggalkannya "argumen metode saja" dalam menentukan strategi pembelajaran bahasa. Guru bahasa dalam hal ini dituntut mampu menemukan strategi dan teknik serta penciptaan suasana pembelajaran yang efektif dalam memperkaya proses pengajarannya. ${ }^{26}$

Selain itu, guru bahasa Arab juga diharapkan mampu mengembangkan pembelajaran bahasa Arab berbasis teknologi informasi dan komunikasi (ICT) dan pembelajaran bahasa Arab berbasis riset. Karena itu, pembelajaran bahasa Arab di era posmetode juga perlu dikembangkan berdasarkan hasil-hasil riset mutakhir. Pembelajaran Bahasa Arab Berbasis Riset (PBABR) bukan sekadar menyampaikan materi ajar kepada siswa, melainkan merupakan pembelajaran yang dilandasi hasil-hasil riset, penelaahan dan pengkajian materi bahasa Arab secara akademik dan

26 Arda Arikan, "Postmethod Condition and Its Implication for Language Teacher Education", dalam Journal of Language and Linguistic Studies, Vol. 2, No. 1, April 2006, h. 2. komprehensif. PBABR didesain menurut teknologi pendidikan dan pembelajaran: rancang-bangun pembelajaran bahasa Arab bersendikan ilmu bahasa Arab, linguistik edukasional, psikolinguistik, sosiolinguistik, dan sebagainya. Kesatuan integral antara materi, strategi, metode, media dan penciptaan suasan pembelajaran bahasa Arab yang kondusif dipersiapkan dengan cermat, relevan, dan efektif. Selain itu, PBABR juga menghendaki standarisasi dan profesionalisasi, tidak sekadar mempresentasikan materi ajar bahasa Arab tanpa dilandasi hasil-hasil riset yang memadai. Karena itu, etos dan budaya meneliti perlu ditumbuhkembangkan di kalangan guru/dosen dan siswa, agar kedua belah bisa saling berkolaborasi dalam mengonstruksi pengatahuan kebahasaaraban, berlatih mengembangkan keterampilan berbahasa Arab, dan sekaligus mengembangkan ilmu yang terkait dengan bidang yang ditekuninya.

Dengan demikian, PBABR menghendaki upaya terus-menerus dalam updating informasi dan perkembangan keilmuan, dengan senantiasa memanfaatkan ICT. Standarisasi dan profesionalisasi pembelajaran bahasa Arab juga harus dibarengi dengan pengelolaan dan pengembangan sistem pembelajaran sesuai dengan standar keilmuan dan profesi secara baik dan benar. Tujuan, kurikulum (kompetensi dan materi), pendekatan, metode, dan media pembelajaran bahasa Arab perlu dirumuskan sesuai dengan kelayakan, kepatutan, kebutuhan, dan kemutakhiran informasi keilmuan.

Dalam praktiknya, PBABR dapat dirancang dengan beberapa langkah sebagai berikut. Pertama, penetapan dan pengembangan kurikulum berdasarkan standar keilmuan yang jelas (didiskusikan 
dan dimatangkan dalam konsorsium dosen), bukan menurut selera subjektif. Kedua, penyusunan silabi dan bahan ajar secara akademik dengan didasari riset terhadap sumber-sumber terkait melalui ICT dan media lainnya. Ketiga, uploading silabi dan bahan ajar dalam blog. Keempat, pengayaan dan pengembangan bahan ajar menjadi buku atau karya ilmiah yang memadai. Kelima, diskusi, seminar, dan pematangan karya ilmiah sehingga menjadi siap dan layak diterbitkan. ${ }^{27}$

PBABR bukan hanya monopoli dosen/guru, melainkan juga dapat melibatkan partisipasi mahasiswa. Para mahasiswa dapat dilatih dan dibiasakan mengembangkan pemikirannya dengan melacak, mencari, mengumpulkan, mengolah, menganalisis, dan membuat laporan riset (karya ilmiah) yang bermutu. Hal ini akan menjadi produktif, jika hasil riset (karya ilmiah) dapat dipublikasikan dalam jurnal on line yang sudah disitasi oleh lembaga-lembaga sitasi.

Jika sebuah topik bahasan dalam perkuliahan memerlukan riset pengembangan (lanjutan), maka dimungkinkan dilakukan riset (penelitian) kolektif secara terpadu dan berkelanjutan. Misalnya, topik bahasan perkuliahan mengenai "kolokasi" atau sanding kata (tadhâmm). Materi ini kemungkinan besar tidak selesai dibelajarkan dalam satu kali tatap muka, maka untuk lebih melengkapi dan mengembangkan materi, dosen dan mahasiswa melakukan riset bersama mengenai, misalnya "Ragam kolokasi

\footnotetext{
27 Langkah-langkah tersebut merupakan pendapat penulis didasarkan pada pengalaman empirik dan pembacaan terhadap sejumlah buku metodologi penelitian. Di antaranya adalah Abdullah as-Sulami dan Mukhtar al-Ghauts, Manhaj al-Bahts fi al-Lughah wa al-Adab dan B. Bartschat, Manâhij 'Ilm al-Bahts, Terjemahan ke dalam bahasa Arab oleh Said Husain Buhairi.
}

dan konteks penggunaannya dalam alQur'an atau koran-koran Arab". Semua materi bahasa Arab pada dasarnya dapat dikembangkan melalui riset (qâbil li albahts wa al-dirâsah); dan penyajian materi bahasa Arab dapat diperkaya dengan aneka pendekatan, strategi, dan teknik mengajar atau membelajarkan yang aktif, efektif, konstruktif, kreatif, menyenangkan, dan produktif (menghasilkan karya, meningkatkan kompetensidanketerampilan berbahasa, sekaligus pengalaman belajar yang mengesankan).

Untuk merealisasikan PBABR, diperlukan adanya keseriusan berbagai pihak, terutama para pimpinan perguruan tinggi (untuk lebih peduli terhadap fasilitasi riset), dosen (dengan memaksimalkan kompetensi penelitiannya), dan mahasiswa (dengan menumbuhkembangkan daya baca dan minat meneliti). Karena itu, model berpikir kreatif, kritis, dan inovatif perlu digalakkan. Budaya membaca dan menulis dengan sekedar "copy paste" harus dikembangkan ke arah "karya kreatif dan inspiratif".

Sehubungan dengan itu, komunitas pembelajaran bahasa Arab perlu membentuk semacam bank informasi dan data PBA, sekaligus merancang strategi dan media pembelajaran bahasa Arab yang lebih interaktif dan komunikatif. Sebagai bank, PBABR perlu memiliki lembaga (wadah organisasi) yang menghimpun dan mengoptimalkan tenaga-tenaga peneliti PBA dalam mengembangkan sumber daya PBA, termasuk informasi dan data PBA. Sebagai strategi, PBABR harus menjadi komitmen setiap warga komunitas PBA dalam menjalankan profesinya sebagai dosen, guru atau tenaga pelatih bahasa Arab. Dan, sebagai media, PDBR idealnya terus-menerus mengembangkan media 
pembelajaran untuk setiap pokok bahasan dari semua matakuliah.

Menurut penulis, masing-masing lembaga pendidikan perlu memiliki dan memberdayakan tenaga ICT (tidak hanya pustakawan dan laboran) yang fungsinya dapat diintegrasikan ke dalam laboratorium multimedia. Dengan demikian, dosen atau guru dapat bekerjasama dengan tenaga ICT dalam mengembangkan materi dan media pembelajaran bahasa Arab secara lebih hidup, menarik, interaktif, dan efektif. Orientasi pembelajaran bahasa Arab yang memenuhi proses pembelajaran tiga unsur bahasa (ashwât, mufradât, dan tarâkib) dan pencapaian tujuan 3 kompetensi (kifâyah lughawiyyah, kifâyah ittishâliyyah, dan kifâyah ijtima'iyyah tsaqâfiyyah) ${ }^{28}$ perlu dikembangkan lebih lanjut menuju pemenuhan kompetensi strategis (strategic competence) dan kompetensi analisis wacana (discourse competence) ${ }^{29}$. Oleh karena itu, dengan basis riset yang kuat dan berkelanjutan, pembelajaran bahasa Arab di era posmetode dapat dikembangkan dan disajikan secara lebih menarik, sesuai dengan kebutuhan peserta didik, perkembangan ilmu, dan tuntutan zaman.

\section{Simpulan}

Pembelajaran bahasa Arab di dunia Islam dan di Indonesia, dari tahun ke tahun, mengalami perkembangan yang berarti, meskipun "selalu kalah cepat" dengan perkembangan pembelajaran bahasa Inggris. Keterlambatan kita dalam

28 Lihat Abdurrahman ibn Ibrahim al-Fauzan, dkk, al-Arabiyyah Baina Yadaik: Kitâb at-Thâlib I, (Riyadh: al-Arabiyyah li al-Jami', 2005), Cet. III, h.ts.

29 M. Canale and M. Swain, "Theoritical Basis of Communicative Approaches to Second Language Teaching and Testing", Apllied Language, Vol. 1, No. 1, 1980, h.47; dan lihat juga Rusydi Ahmad Thu'aimah, Ta'lim al-'Arabiyyah li Ghair an-Nâthiqina bihâ: Manâhijuhu wa Asâlîbuhu..., h. 120 mengembangkan metodologi pembelajaran bahasa Arab memang dapat dimaklumi, karena kita masih belajar dan menjadi konsumen dari "temuan, teori, dan ilmuilmu" yang dikembangkan para akademisi Barat. Bahkan mayoritas akademisi dan pemikir di bidang metodologi pembelajaran bahasa Arab hampir pasti "merujuk dan mengadaptasi" berbagai pemikiran di bidang pembelajaran bahasa Arab yang sudah berkembang terlebih dahulu di dunia Barat.

Oleh karena itu, untuk lebih mengembangkan dan memajukan pembelajaran bahasa Arab ke depan, diperlukan usaha kolektif (ijtihâd jamâ'i) yang serius dari pada ulama bahasa Arab dengan melakukan berbagai riset komprehensif, kolaboratif, dan eksperimen tentang "Bagaimana membelajarkan bahasa Arab itu menjadi lebih menarik, mengesankan, menginspirasi, menyenangkan, dan memahirkan?" Inilah pekerjaan rumah kita semua.

Di era posmetode ini, faktor sumber daya manusia (guru/dosen, peserta didik/siswa/mahasiswa, dan tenaga kependidikan) memainkan peran kunci dalam membelajarkan bahasa Arab. Guru atau dosen tidak lagi "bergantung" dan memiliki ketergantungan pada metode tertentu dalam membelajarkan bahasa Arab. Bahkan, dengan ditemukankan teori kecerdasan majemuk (multiple intellegencies) oleh Gardner, guru/dosen harus dapat meramu dan memadukan aneka strategi, bahan ajar, dan media pembelajaran bahasa Arab berbasis ICT yang efisien dan efektif. Selain itu, riset berbasis multidisiplin ilmu (psikologi, linguistik, antropologi, ekonomi bahasa, sosiologi, budaya, neurolinguistik, pragmatik, politik, pendidikan, dan sebagainya) untuk 
pengembangan pembelajaran bahasa Arab juga perlu dilakukan, sehingga pembelajaran bahasa Arab tidak berhenti pada tataran mengenalkanstruktur dan gramatikabahasa Arab, melainkan juga memahirkan empat keterampilan bahasa, dan memampukan peserta didik menganalisis wacana dan memiliki kompetensi strategis dalam berkomunikasi dalam bahasa Arab, baik lisan maupun tulisan. Jadi, bukan metode lebih penting daripada materi bahasa Arab, melainkan profesionalitas dan pemahaman guru terhadap peran dan fungsinya sebagai intelektual transformatif itu lebih penting daripada metode itu sendiri. Wallahu a'lam bi as-shawâb! []

\section{Daftar Rujukan}

Arikan, Arda, "Postmethod Condition and Its Implication for Language Teacher Education", dalam Journal of Language and Linguistic Studies, Vol. 2, No. 1, April 2006, h. 2.

Asrori, Imam, Strategi Belajar Bahasa Arab: Teori dan Praktik, Malang: Misykat, 2011.

Bartschat, B., Manahij 'Ilm al-Bahts, Terjemahan ke dalam bahasa Arab oleh Said Husain Buhairi.

Bell, David M. "Method and Postmethod: Are They Really so Incompatible?" dalam TESOL Quarterly, Vol. 37, No. 2, Summber 2003.

Brown, Douglas H., Prinsip Pembelajaran dan Pengajaran Bahasa, Terjemahan Noor Cholis dan Yusi Avianto Parianom, Edisi Kelima, Jakarta: Kedubes Amerika Serikat, 2007.

Canale, M. and M. Swain, "Theoritical Basis of Communicative Approaches to Second Language Teaching and Testing", Apllied Language, Vol. 1, No. 1, 1980.
ad-Dhawi, Munif Hudhair, an-Nazhariyyah al-Binâ'iyyah wa Tathbîquhâ fi Tadrîs al-Lughah al-'Arabiyyah: Istirâtîjiyyah

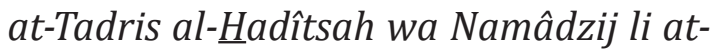
Taqwîm al-Binâ'î, Riyadh: Mathâbi' alHumaidhi, 2013.

Effendy, Ahmad Fuad, Metodologi Pembelajaran Bahasa Arab, Malang: Misykat, 2005.

al-Fauzan, Abdurrahman ibn Ibrahim, dkk, al-Arabiyyah Baina Yadaik: Kitâb atThâlib I, Riyadh: al-Arabiyyah li al-Jami', Cet. III, 2005.

al-Hadidi, Ali, Musykilât Ta'lîm al-Lughah al'Arabiyyah li ghair al-Arab, Kairo: Dâr alKâtib al-'Arabi, 1966.

Hazratzad, Ahmad dan Mehrnaz Gheitanchian, 'EFL Teachers' Attitudes towards Post-method Pedagogy and Their Students' Achievement", dalam Proceedings of the 10th METU ELT Convention, 2010.

Jabir, Walid Ahmad, Tadrîs al-Lughah al'Arabiyyah: Mafâhîm Nazhariyyah wa Tathbîqât 'Amaliyyah, 'Amman: Dâr alFikr, Cet. I, 2002.

Khalifah, Hasan Ja'far, Fushûl fi Tadrîs al-Lughah al-'Arabiyyah (Ibtidâ'iMutawassith-Tsânawi), Riyadh: Maktabah ar-Rusyd, Cet. II, 2003.

Khathir, Mahmud Rusydi, dkk., Thuruq Tadrîs al-Lughah al-Arabiyyah wa at-Tarbiyah ad-Dîniyyah fi Dhaui al-Ittijâhât atTarbawiyyah al-ㅍadîtsah, Kairo: Dâr alMa'rifah, 1983.

Khurma, Nayif dan Ali Hajjaj, al-Lughat alAjnabiyyah: Ta'limuha wa Ta'allumuha, al-Kuwait: 'Âlam al-Ma'rifah, 1988.

Kumaravadivelu, Beyond Methods: Macrostrategies for Language Teaching, Yale: Yale University Press, 2003. 
Liu, Jun, "Methods in the Post-Methods Era: Report on an International Survey on Language Teaching Methods", dalam IJES (International Journal of English Studies), Vol. 4 (4), 2004.

Machmudah, Umi dan Rosyidi, Abdul Wahab. Active Learning untuk Pembelajaran Bahasa Arab, Editor: Mujtahid, Malang: UIN-Malang Press, 2008.

Murray, Jill, "Teacher competencies in the post-method landscape: The limits of competency-based training in TESOL teacher education", dalam Australian and New Zealand Journal of Vocational Education Research, 2009 Volume 24, No 1.

ar-Rukkabi, Jaudat, Thuruq Tadrîs al-Lughah al-Arabiyyah, Damaskus: Dâr al-Fikr, 1986.

as-Sulami, Abdullah dan Mukhtar al-Ghauts, Manhajal-Bahtsfi al-Lughah wa al-Adab, Jeddah: Khawarizm al-'Ilmiyyah, 2014.
Thu'aimah, Rusydi Ahmad dan Muhammad Kamil an-Naqah, al-Kitâb al-Asâsi li Ta'lîm al-Lughah al-'Arabiyyah li anNâthiqâna bi Lughat Ukhrâ: I'dâduhu, Tahliluhu-Taqwîmuhu, Mekkah: Jâmi'ah Umm al-Qura, 1983.

Thu'aimah, Rusydi Ahmad dan Muhammad as-Sayyid Manna', Tadrîs al-'Arabiyyah fi at-Ta'lîm al-'̂́mm dan Ta'lîm al'Arabiyyah wa ad-Dîn, Kairo: Dâr al-Fikr al-'Arabî, 2000.

Thu'aimah, Rusydi Ahmad, Ta'lîm al-Lughah al-Arabiyyah li Ghair an-Nâthiqîna bihâ: Manâhijuhu wa Asâlîbuhu, Rabath: ISESCO, 1989.

Yunus, Fathi Ali, dkk, Asâsiyyât Ta'lîm alLughah al-Arabiyyah wa at-Tarbiyah ad-Dîniyyah, Kairo: Dâr as-Tsaqâfah, 1984.

Yunus, Fathi Ali, Tashmîm Manhaj Ta'lîm alLughah al-'Arabiyyah li al-Ajânib (Bahts Tajrîbî), Kairo: Dâr al-Tsaqâfah, 1978. 